\section{Cureus}

\title{
Small Cell Carcinoma of the Hypopharynx
}

\author{
Ruixiang Sun ${ }^{1}$, Alysa Fairchild ${ }^{2}$, Brock Debenham ${ }^{3}$ \\ 1. Faculty of Medicine and Dentistry, University of Alberta, Edmonton, CAN 2. Radiation Oncology, \\ Cross Cancer Institute, University of Alberta, Edmonton, CAN 3. Radiation Oncology, Cross Cancer \\ Center, University of Alberta, Edmonton, CAN
}

$\square$ Corresponding author: Ruixiang Sun, ruixiang@ualberta.ca

Disclosures can be found in Additional Information at the end of the article

\section{Abstract}

Small cell carcinoma is rarely found to originate from the hypopharynx and there exists no treatment guidelines due to the small number of cases. Here, we present a case of a female patient with metastatic small cell carcinoma originating from the posterior hypopharynx with lymph node involvement. Her treatment consisted of chemotherapy with etoposide and cisplatin as well as radiation therapy. Her post-treatment computed tomography (CT) scan indicated resolution of the disease at the primary site and follow-up positron emission tomography (PET)-CT scan at three-month post radiation therapy revealed that the patient is clear of the disease.

Categories: Radiation Oncology, Oncology

Keywords: hypopharynx, extrapulmonary small cell carcinoma, chemotherapy, radiation treatment, prophylactic cranial radiotherapy

\section{Introduction}

Small cell carcinoma is an aggressive form of cancer that most commonly arise in the lungs, accounting for approximately $20 \%$ of all lung cancers [1]. Extrapulmonary manifestations of small cell carcinoma are rare, consisting of $2.5 \%-5 \%$ of all small cell carcinomas [2]. In the head and neck region, the larynx is the most common site and the hypopharynx is an extremely rare site for extrapulmonary small cell carcinoma [3]. Due to the small number of cases reported for small cell carcinoma of the hypopharynx, there exists no standards or guideline for treatment. Previous treatments include chemotherapy, radiation therapy, or a combination of chemotherapy and radiation. Primary surgical resection and neck dissection have in most cases failed for small cell carcinoma in the larynx and hypopharynx [4]. The median overall survival rate for laryngeal and hypopharyngeal small cell carcinoma was found to be 17.9 months and the median two-year survival rate was found to be $40.6 \%$ [5]. We present a case of primary small cell carcinoma of the hypopharynx in a 67-year-old female patient.

Received 05/30/2018

Review began 06/22/2018 Review ended 07/11/2018 Published 07/16/2018

\section{(C) Copyright 2018}

Sun et al. This is an open access article distributed under the terms of the Creative Commons Attribution License CC-BY 3.0., which permits unrestricted use, distribution, and reproduction in any medium, provided the original author and source are credited.

\section{Case Presentation}

The patient presented to her family physician with a six-month history of a fluctuating neck mass. An ultrasound of the neck was obtained, which showed an abnormal lesion noted between the submandibular gland and the carotid vasculature suggestive of a grossly abnormal lymph node. A biopsy was obtained, which revealed metastatic small cell carcinoma. A chest Xray was done, which was normal. A computed tomography (CT) scan of the head, chest, abdomen, and pelvis was done, which showed no evidence of disease in the chest or abdomen, but did show soft tissue fullness in the posterior hypopharynx. A positron emission tomography (PET)-CT scan was done, which showed prominent large left-sided level II lymph nodes measuring $3.9 \times 2.1 \mathrm{~cm}$ with increased metabolic activity, as seen in Figure 1 . The hypopharynx 


\section{Cureus}

also was fluorodeoxyglucose(FDG)-avid, as well as a contralateral level II lymph node.

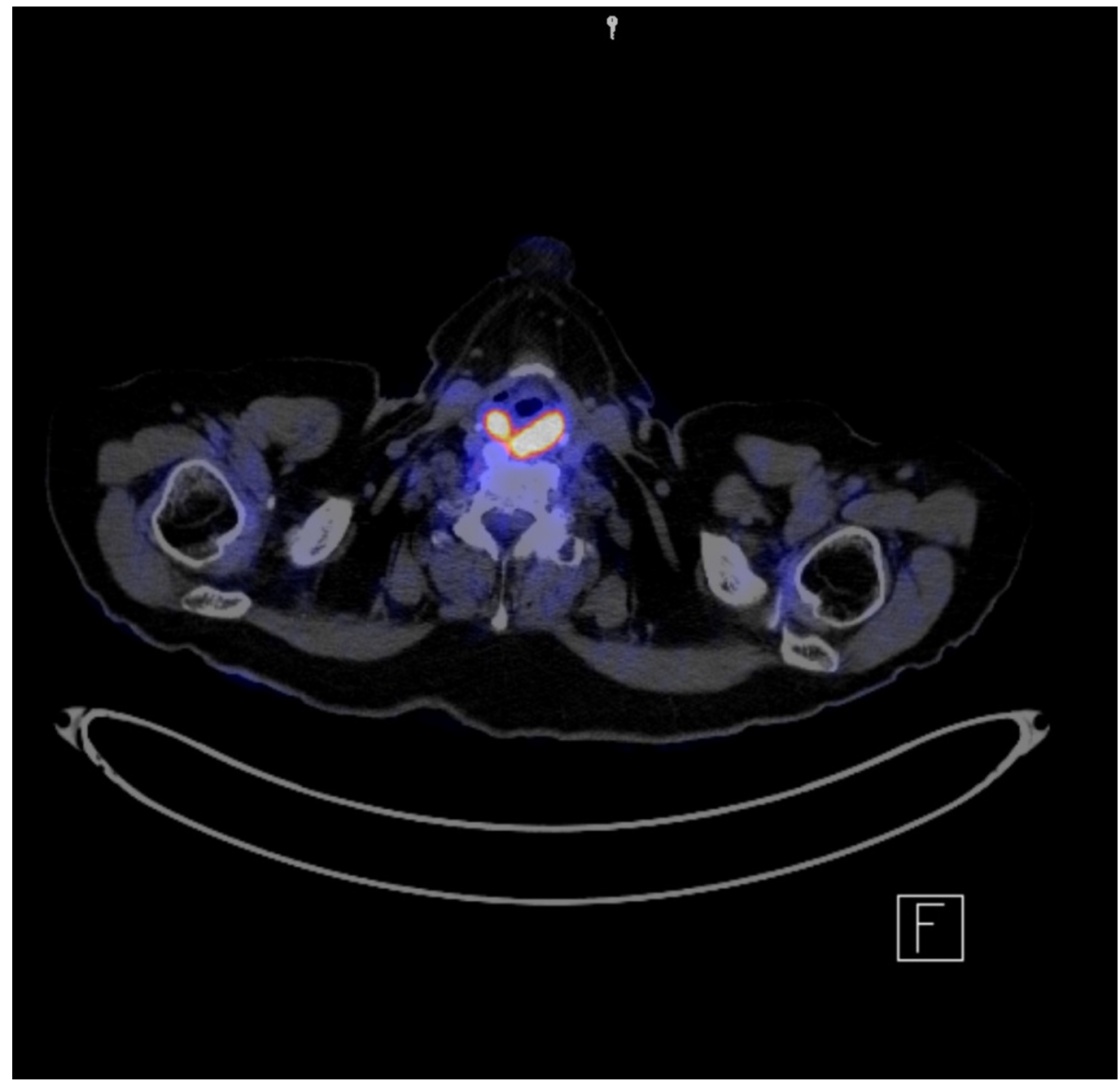

\section{FIGURE 1: Pre-treatment positron emission tomography- computed tomography (PET/CT) scan}

Past medical history was significant for hypertension, dyslipidemia, alcoholism, and hypothyroidism. She is a current smoker, with a previous 50 pack year smoking history.

She was started on cisplatin and etoposide chemotherapy. She began radiotherapy concurrently with her second cycle of chemotherapy. She received $60 \mathrm{~Gy}$ in 30 fractions to the gross disease and bilateral neck using a volumetric modulated arc therapy (VMAT) plan. She required placement of a percutaneous endoscopic gastrostomy (PEG) tube at the end of her treatment for nutritional support. She was planned for four cycles of chemotherapy, but only received three due to poor performance status. She did not receive prophylactic cranial irradiation (PCI).

Her initial post-treatment CT scan, done six weeks post treatment, demonstrated resolution of the primary site of disease, and a single remaining lymph node measuring $1 \mathrm{~cm}$ where it previously measured $3.9 \mathrm{~cm}$. No distant disease was seen. CT head was normal. She had another PET/CT scan at three months post radiation therapy and was also clear of disease, as seen in Figure 2. 


\section{Cureus}

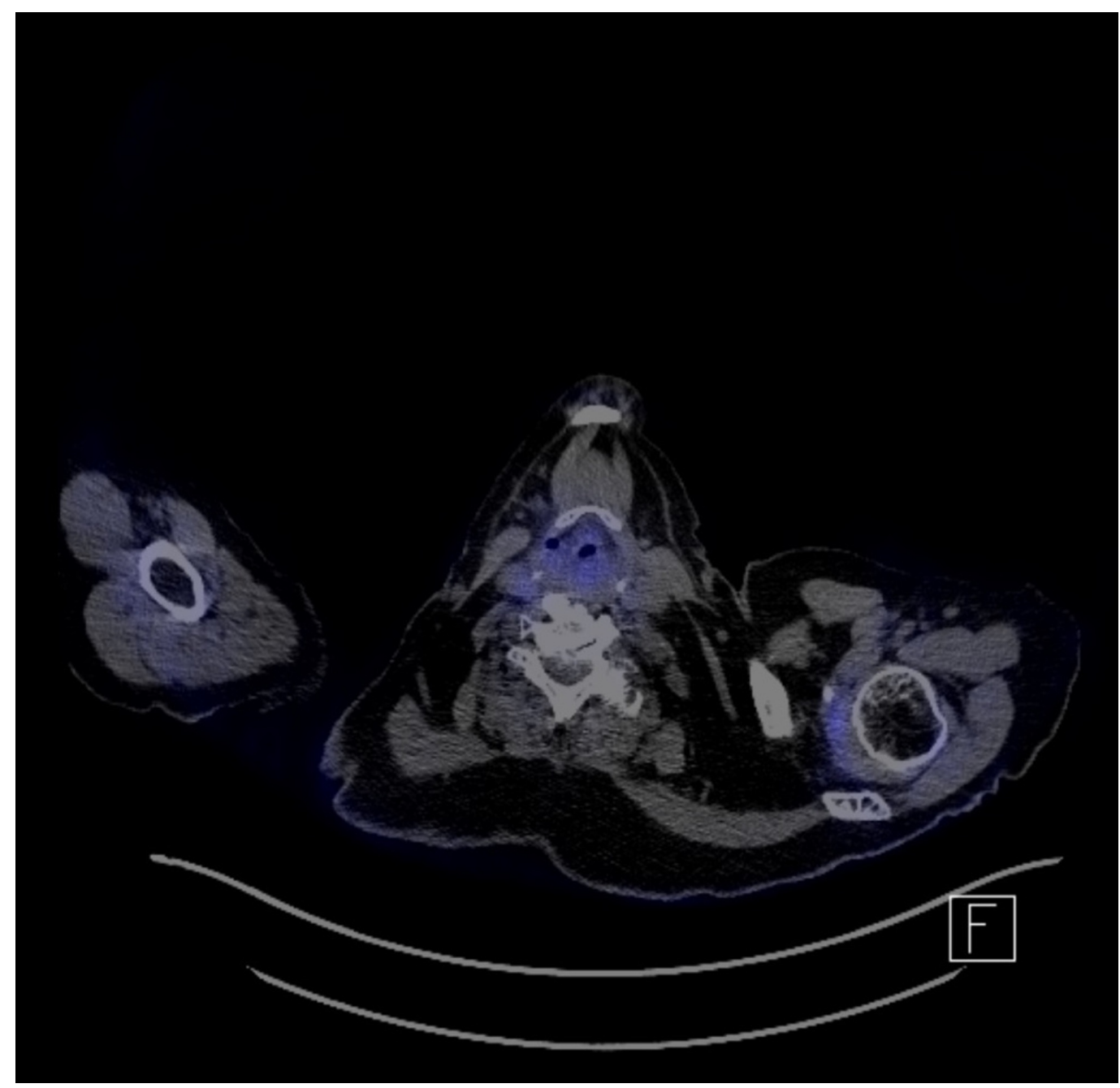

FIGURE 2: Post-treatment positron emission tomographycomputed tomography (PET/CT) scan

\section{Discussion}

There have been cases reporting on hypopharyngeal small cell carcinoma and they are summarized in Table 1. Only cases reporting pure small cell carcinomas of the hypopharynx have been included. There are cases reporting combined small cell and squamous cell carcinomas of the hypopharynx; however, they have been excluded as the treatment guidelines for squamous cell carcinomas do not apply for small cell carcinomas.

\begin{tabular}{|c|c|c|c|c|c|c|}
\hline Author & Year & Age/Sex & $\begin{array}{l}\text { Smoking/Alcohol } \\
\text { History }\end{array}$ & Metastasis & Treatment & Outcome \\
\hline $\begin{array}{l}\text { Lee et } \\
\text { al. [3] }\end{array}$ & 2016 & 71/M & $\begin{array}{l}50 \text { pack-year } \\
\text { smoking history. } \\
\text { History of heavy } \\
\text { alcohol use. }\end{array}$ & $\begin{array}{l}\text { Hypermetabolic } \\
\text { mediastinal } \\
\text { lymph nodes } \\
\text { found. }\end{array}$ & $\begin{array}{l}\text { Chemotherapy: } \\
\text { cisplatin and } \\
\text { etoposide. Radiation: } \\
70 \text { Gy in } 35 \text { fractions. }\end{array}$ & $\begin{array}{l}\text { Complete response to } \\
\text { treatment; no evidence of } \\
\text { recurrence over } 11 \text { months } \\
\text { of follow up. }\end{array}$ \\
\hline
\end{tabular}




\section{Cureus}

\begin{tabular}{|c|c|c|c|c|c|c|}
\hline $\begin{array}{l}\text { Bayram } \\
\text { et al. [6] }\end{array}$ & 2015 & $50 / \mathrm{M}$ & $\begin{array}{l}60 \text { pack-year } \\
\text { smoking history. }\end{array}$ & $\begin{array}{l}\text { Metastatic } \\
\text { nodules found } \\
\text { in lungs. }\end{array}$ & $\begin{array}{l}\text { cisplatin and } \\
\text { etoposide. Radiation: } \\
2.12 \mathrm{~Gy} / \text { fraction/day } \\
\text { until } 16^{\text {th }} \text { session. }\end{array}$ & $\begin{array}{l}\text { complete response } \\
\text { achieved at primary tumor } \\
\text { site and the neck. The } \\
\text { patient remained disease- } \\
\text { free for } 15 \text { months. }\end{array}$ \\
\hline $\begin{array}{l}\text { Treglia } \\
\text { et al. [7] }\end{array}$ & 2014 & $64 / \mathrm{M}$ & Unknown & $\begin{array}{l}\text { Lymph node } \\
\text { and bone } \\
\text { metastasis } \\
\text { were found. }\end{array}$ & Chemotherapy only. & $\begin{array}{l}\text { Died eight months later due } \\
\text { to disease progression. }\end{array}$ \\
\hline $\begin{array}{l}\text { aba et } \\
\text {. [8] }\end{array}$ & 2005 & 65/M & $\begin{array}{l}\text { Excessive alcohol } \\
\text { consumption. } \\
\text { Remote tobacco } \\
\text { history. }\end{array}$ & $\begin{array}{l}1.5 \mathrm{~cm} \text { level III } \\
\text { ipsilateral } \\
\text { cervical lymph } \\
\text { node. No } \\
\text { pulmonary or } \\
\text { distant } \\
\text { metastasis }\end{array}$ & $\begin{array}{l}\text { Laser debulking. } \\
\text { Chemotherapy: } \\
\text { platinum-based } \\
\text { chemotherapy } \\
\text { Radiation: } 69 \text { Gy of a } \\
\text { planned } \\
\text { hyperfractionated } \\
\text { course of } 74.4 \text { Gy to } \\
\text { the primary tumor. }\end{array}$ & $\begin{array}{l}\text { Complete clinical response } \\
\text { at } 24 \mathrm{~Gy} \text {. The patient } \\
\text { remains disease-free two } \\
\text { years after diagnosis. }\end{array}$ \\
\hline $\begin{array}{l}\text { ano et } \\
\text {. [4] }\end{array}$ & 2005 & $67 / F$ & $\begin{array}{l}80 \text { pack-year } \\
\text { smoking history. } \\
\text { History of alcohol } \\
\text { use. }\end{array}$ & $\begin{array}{l}\text { Right neck } \\
\text { lymph node } \\
\text { involvement. }\end{array}$ & $\begin{array}{l}\text { Chemotherapy: } \\
\text { carboplatin (CBDCA) } \\
\text { and etoposide (VP-16) } \\
\text { Radiation: } 54 \text { Gy (1.8 } \\
\text { Gy x } 30 \text { fractions over } \\
\text { seven weeks) } \\
\text { delivered to the } \\
\text { primary site, } \\
\text { hypopharynx, and right } \\
\text { neck lymph nodes. }\end{array}$ & $\begin{array}{l}\text { Complete response was } \\
\text { achieved with } \\
\text { chemotherapy, but one } \\
\text { month after last radiation, } \\
\text { lung and liver metastasis } \\
\text { appeared. Chemotherapy } \\
\text { given but the patient died of } \\
\text { lung and liver metastasis } 13 \\
\text { months after initial } \\
\text { diagnosis. }\end{array}$ \\
\hline $\begin{array}{l}\text { oshida } \\
\text { al. [1] }\end{array}$ & 2005 & 78/M & $\begin{array}{l}50 \text { pack-year } \\
\text { smoking history. } \\
\text { Moderate alcohol } \\
\text { use. }\end{array}$ & $\begin{array}{l}\text { No distant } \\
\text { metastasis. }\end{array}$ & $\begin{array}{l}\text { Chemotherapy: } \\
\text { docetaxel, cisplatin, 5- } \\
\text { FU Radiation: } 2 \\
\text { Gy/day, five } \\
\text { days/week. Total of } 54 \\
\text { Gy over } 27 \text { fractions. }\end{array}$ & $\begin{array}{l}\text { Since initial } \\
\text { chemoradiotherapy, the } \\
\text { patient has been free of } \\
\text { disease for three years and } \\
\text { there were no evidence of } \\
\text { late complications of } \\
\text { radiotherapy. }\end{array}$ \\
\hline $\begin{array}{l}\text { augh } \\
\text { al. [9] }\end{array}$ & 1986 & $63 / F$ & $\begin{array}{l}\text { No tobacco or } \\
\text { alcohol history. }\end{array}$ & $\begin{array}{l}\text { No distant } \\
\text { metastasis. }\end{array}$ & $\begin{array}{l}\text { Surgical resection of } \\
\text { largest neck mass. } \\
\text { Chemotherapy: } \\
\text { doxorubicin, Cytoxan, } \\
\text { vincristine. }\end{array}$ & $\begin{array}{l}\text { Right vocal cord remains } \\
\text { paralyzed in the } \\
\text { paramedian position. } 55 \\
\text { months after initial } \\
\text { diagnosis there were no } \\
\text { evidence of recurrence of } \\
\text { tumor. }\end{array}$ \\
\hline $\begin{array}{l}\text { augh } \\
\text { al. [9] }\end{array}$ & 1986 & $35 / \mathrm{M}$ & $\begin{array}{l}\text { No smoking } \\
\text { history. Heavy } \\
\text { Use of alcohol. }\end{array}$ & None. & $\begin{array}{l}\text { Radiation: } 66 \text { Gy over } \\
35 \text { fractions delivered } \\
\text { over } 57 \text { days to } \\
\text { primary site and neck. }\end{array}$ & $\begin{array}{l}\text { No evidence of disease } 21 \\
\text { months after diagnosis. }\end{array}$ \\
\hline
\end{tabular}




\section{Cureus}

\section{TABLE 1: Cases of small cell carcinoma of the hypopharynx}

Extrapulmonary small cell carcinomas are rare tumors that make up approximately $2.5-5 \%$ of small cell carcinomas [2]. They most frequently arise in the gastrointestinal and genitourinal tract, such as the esophagus and bladder [10]. For all sites in the head and neck region, the median survival is 20.3 months with a two-year overall survival of $45.2 \%$ [5]. Due to a low number of cases, treatment modalities for extrapulmonary small cell carcinomas have been based on case reports and series as well as treatment regimens for small cell carcinomas of the lung. It has been suggested that surgical resection and radiation be used for regional treatment while for relapses and metastasis chemotherapy regimens modelled after small cell carcinomas of the lung should be used [11]. For example, for early stages of small cell carcinoma of the bladder, transurethral resection of cystectomy is the initial treatment modality [11]. For extensive disease, the treatment regimen for small cell carcinoma, platinum-based chemotherapy with etoposide were found to prolong survival [10]. This was the chemotherapy regimen used in majority of case reports on hypopharngeal small cell carcinoma with favourable results, and was also used for the patient discussed in the report.

In the head and neck region, the most common site for extrapulmonary small cell carcinoma is the larynx $[3,5]$. Surgery is not recommended for primary treatment due to distant metastasis, local recurrence, as well as poor prognosis of the disease as surgical resection procedures such as total laryngectomy cause a significant decrease in quality of life [12]. The treatment for laryngeal small cell carcinoma with the best results is concurrent or sequential chemoradiotherapy commonly using platinum-based chemotherapy agents with etoposide [13]. This is similar to the chemotherapy regimen applied in most of the cases of hypopharyngeal small cell carcinoma presented here. Despite treatment, local and distant metastasis are common and prognosis are poor for laryngeal small cell carcinoma [13].

None of the pure small cell carcinomas of the hypopharynx cases reported gave PCI as part of the treatment plan. The literature remains controversial regarding giving PCI to patients with small cell carcinoma of the head and neck. Yacizi suggested that since extrapulmonary primary small cell carcinoma in the head and neck region have a high incidence of brain metastasis at $41 \%$, PCI should be considered for these patients [14]. While Mason suggests that brain metastases are rare for these patients and prophylactic cranial irradiation is not warranted [15].

There are no guidelines for doses of radiation used to control the disease, although most cases indicate a high dose radical radiation dose of at least $50 \mathrm{~Gy}$, except for palliative cases. This is similar for both laryngeal and hypopharyngeal small cell carcinoma [13]. Most of the cases reviewed employ radiation therapy in conjunction with chemotherapy.

Small cell carcinoma remains a cancer with relatively poor prognosis and due to a low incidence of extrapulmonary cases, especially those in the hypopharynx, large-scale studies and trials cannot be conducted. It would be beneficial to consider advancements in treatment modalities for small cell carcinomas of the lung, such as immunotherapy and apply them to extrapulmonary small cell carcinomas. Small cell lung cancer is closely related to abnormal regulation of autoimmunity, and promising advances have been made with immune checkpoint blockers [16].

\section{Conclusions}

Small cell carcinoma is rarely found to originate from the hypopharynx. Due to the low number of cases, there are no guidelines available to guide treatment. Combined chemotherapy and 
radiation therapy was found to be a common treatment regimen as guided by treatment for small cell carcinoma of the lung.

\section{Additional Information \\ Disclosures}

Human subjects: Consent was obtained by all participants in this study. Conflicts of interest: In compliance with the ICMJE uniform disclosure form, all authors declare the following:

Payment/services info: All authors have declared that no financial support was received from any organization for the submitted work. Financial relationships: All authors have declared that they have no financial relationships at present or within the previous three years with any organizations that might have an interest in the submitted work. Other relationships: All authors have declared that there are no other relationships or activities that could appear to have influenced the submitted work.

\section{References}

1. Yoshida K, Hiratsuka J, Tanimoto D, Gyoten M, Sadahira Y, Imajo Y: Extrapulmonary small cell carcinoma of the hypopharynx: a case report. Kawasaki Med J. 2005, 31:63-68.

2. Renner G: Small cell carcinoma of the head of neck: a review . Semin Oncol. 2007, 34:3-14. 10.1053/j.seminoncol.2006.10.024

3. Lee JH, Jeong JS, Kim SR, Lee YC: Small cell carcinoma of the pyriform sinus successfully treated with concurrent chemo-radiotherapy. Medicine (Baltimore). 2016, 95:4759. 10.1097/MD.0000000000004759

4. Sano M, Kitahara N, Toma M: Hypopharyngeal small cell carcinoma: a case report . Auris Nasus Larynx. 2005, 32:319-322. 10.1016/j.anl.2005.03.011

5. Pointer KB, Ko HC, Brower JV, et al.: Small cell carcinoma of the head and neck: an analysis of the National Cancer Database. Oral Oncol. 2017, 69:92-98.

10.1016/j.oraloncology.2017.04.009

6. Bayram A, Akay E, Göksu SS, Özcan E: Primary small cell carcinoma of the hypopharynx: a case report of a rare tumor. Case Rep Otolaryngol. 2015, 2015:934926. 10.1155/2015/934926

7. Treglia G, Bongiovanni M, Paone G, Ruberto T, Parvex-Leoni S, Giovanella L: Metastatic small cell neuroendocrine carcinoma of the pyriform sinus evaluated by 18F-FDG PET/CT. Rev Esp Med Nucl Imagen Mol. 2014, 34:125-127. 10.1016/j.remn.2014.04.006

8. Gaba A, Mbaoma R, Breining D, Smith RV, Beitler JJ, Haigentz M Jr: Unusual sites of malignancies: case 1. small cell carcinoma of the hypopharynx. J Clin Oncol. 2005, 23:20942099. 10.1200/JCO.2005.02.130

9. Baugh RF, Wolf GT, McClatchey KD: Small cell carcinoma of the head and neck . Head Neck Surg. 1986, 8:343-354. 10.1002/hed.2890080505

10. Dakhil CSR, Wick JA, Kumar AKL, Satyan MT, Neupane P: Extrapulmonary small cell carcinoma: the University of Kansas experience and review of literature. Med Oncol. 2014, 31:187. 10.1007/s12032-014-0187-1

11. Walenkamp AME, Sonke GS, Sleijfer DT: Clinical and therapeutic aspects of extrapulmonary small cell carcinoma. Cancer Treat Rev. 2009, 35:228-236. 10.1016/j.ctrv.2008.10.007

12. Nakahara S, Takemoto N, Inohara H: Small cell carcinoma of the larynx treated by concurrent chemoradiotherapy: a case report. Case Rep Otolaryngol. 2012, 2012:316165. $10.1155 / 2012 / 316165$

13. Iqbal MS, Paleri V, Moor J, Dobrowsky W, Kelly C, Kovarik J: Small cell neuroendocrine carcinoma of larynx: case series and literature review. J Laryngol Otol. 2015, 129:910-915. $10.1017 /$ S0022215115001668

14. Yazici O, Ozdemir NY, Sendur MAN, Aksoy S, Zengin N: Current approaches for prophylactic cranial irradiation in extrapulmonary small cell carcinoma. Curr Med Res Opin. 2014, 30:1327-1336. 10.1185/03007995.2014.904771

15. Mason M, Giuliani M, Huang SH, et al.: Extra-pulmonary small cell carcinoma in the head and neck setting: the role of prophylactic cranial irradiation. Oral Oncol. 2015, 51:57-59.

10.1016/j.oraloncology.2015.03.014 


\section{Cureus}

16. Li Q, Yuan D, Ma C, et al.: A new hope: the immunotherapy in small cell lung cancer . Neoplasma. 2016, 63:342-350. 10.4149/302 151001N511 